\title{
THE RELATIONSHIP BETWEEN THE EUROPEAN CONVENTION ON HUMAN RIGHTS AND DOMESTIC LAW: A CASE STUDY
}

\author{
Kamil A. Strzępek* \\ Cardinal Stefan Wyszyński University (UKSW), Warsaw, Poland \\ k.strzepek@uksw.edu.pl
}

Received: 19 September 2019 | Revised: 25 February 2020 | Accepted: 8 April 2020

\begin{abstract}
The article is pertaining to the relationship between the European Convention on Human Rights and the Polish national law. Upon the introduction of the system of economic, social and cultural rights contained in the Constitution of the Republic of Poland of 1997, the article considers what rules determine the relationship between the application of the law by Polish courts and the European Court of Human Rights in Strasbourg. The paper concludes by showing how Polish courts and the European Court of Human Rights in Strasbourg refer to the right of property. It's one of the fundamental human rights, when they examine a case. It occurs that clauses, which limit this right, are sometimes understood in a different way by Polish courts and the European Court of Human Rights. Regarding the above, the case of Waldemar Nowakowski $v$. Poland of the European Court of Human Rights in Strasbourg is discussed. Furthermore, the article presents how the Polish Government executes the judgment of the European Court of Human Rights in Strasbourg delivered in the above-mentioned case.
\end{abstract}

Keywords: Constitutional Court, Doctrine of the Margin of Appreciation, Human Rights, Principle of Subsidiarity, Right to Property. 


\section{INTRODUCTION}

The first part of this article presents an extensive system of economic, social and cultural rights in the Constitution of the Republic of Poland of 1997 (hereinafter: the Constitution), as well as how Polish courts interpret these rights. This part of the article aims to familiarize a reader with the system of economic, social and cultural rights in Poland, as well as to indicate the presence of the right to property in the system of rights and freedoms in Poland and to present the interpretation of this right.

The next part of this article presents relations connecting Polish courts with the European Court of Human Rights in Strasbourg (hereinafter: the ECHR) in terms of the principle of subsidiarity and the doctrine of the margin of appreciation.

The last part of this article presents a case study, i.e. the case of Waldemar Nowakowski v. Poland examined by the ECHR, which shows a different interpretative approach of Polish courts and the ECHR to the right to property. The case concerns the violation of Article 1 of Protocol No. 1 to The European Convention on Human Rights due to confiscation of the applicant's collection of antique weapon by domestic courts. The article also presents, on the example of the case of Waldemar Nowakowski v. Poland, how the Polish government executed the judgment of the European Court of Human Rights in Strasbourg delivered in the above-mentioned case.

With regard to constitutional law, the basic method is the analysis of the existing law (dogmatic method). The legal phenomenon, which is the subject of this article, i.e. the relation between the application of the law by Polish courts and the ECHR is described with the help of analysis of the case-law of Polish courts and the ECHR (mainly the case of Waldemar Nowakowski v. Poland). For this reason, references to literature have been kept to a minimum, and the article itself was not intended to constitute a collection and description of the current views on the subject matter of this article. 


\section{THE CONSTITUTION}

The work on the preparation of the current Polish Constitution began in 1989. This was due to political changes that began in Poland in the late 1980 os. The Constitution of the Polish People's Republic of 22 July 1952, being still in force in the 1980s, ceased to meet the needs of changes in Polish society and state.

The Sejm of the Republic of Poland of the first term (1991 - 1993) adopted on 23 April 1992 the Act on the procedure for preparing and adopting the Constitution of the Republic of Poland (hereinafter: the Act). The Act established a constitutional commission that was to deal with the preparation of the final version of the new constitution. The Act also specified that the new constitution would be adopted by the National Assembly, i.e. the combined chambers of the Sejm of the Republic of Poland and the Senate of Poland, and then it would be adopted by the Nation by means of a constitutional referendum. The Act granted the constitutional commission, a group of 56 members of the National Assembly and the President of the Republic of Poland, the right to submit drafts of the new constitution.

On 17 October 1992, the Sejm of the Republic of Poland adopted the Constitutional Act on mutual relations between the legislative and executive authority of the Republic of Poland and on local government. It regulated the basic political system of the state. This act was in force until 16 October 1997, i.e. until the entry into force of the new Constitution of the Republic of Poland of 1997.

Works on the text of the new Polish constitution ended in early 1997. On 2 April 1997, the Constitution was adopted by the National Assembly. On 25 May 1997, a referendum took place, in which the people voted by the majority of $52.71 \%$ of the votes in favor of the Constitution. The turnout in the referendum was $42.86 \%$. On 17 October 1997, the Constitution of the Republic of Poland entered into force. The Constitution consists of a solemn preamble and 243 articles, which are contained in 13 chapters (in some of the subsections have 
been separated). The introduction to the Constitution sets out priority values for Polish society. These include freedom, solidarity, social dialogue, reliability and efficiency of public institutions, respect for and strengthening of civil rights. Individual chapters are entitled: I) Republic; II) Freedoms, Rights and Duties of Man and Citizen; III) Sources of Law; IV) Sejm and Senate; V) the President of the Republic of Poland; VI) Council of Ministers and Government Administration; VII) Local Government; VIII) Courts and Tribunals; IX) State Control and Law Protection Bodies; X) Public Finance; XI) States of Emergency; XII) Amendment of the Constitution; XIII) Transitional and Final Provisions.

\section{ECONOMIC, SOCIAL AND CULTURAL RIGHTS AND FREEDOMS IN THE CONSTITUTION - GENERAL ISSUES}

When it comes to characterizing the system of rights and freedoms in the Constitution, one should first refer to Article 31 of the Constitution, which contains the so-called limitation clauses. The first of these clauses refer to the horizontal application of the law, i.e. to the application of the law in relations between individuals. In such horizontal application of the law, a limitation on the executing of rights and freedoms by an individual is the execution of rights and freedoms by other individuals. Everyone (citizens and foreigners) is obliged to respect the freedoms and rights of others. When executing his/her rights and freedoms, the individual must be mindful of the freedoms and rights of other individuals. This clause should be taken into account by common (civil) courts when resolving disputes between individuals. This provision applies to horizontal relations, i.e. relations between individuals. There are not many such provisions in the Constitution, since most of them refer to vertical relations, i.e. relations between public authorities and individuals.

The remaining limitation clauses refer to vertical relations, i.e. relations between public authorities and individuals. First, it should be stated that in these types of relations, restrictions on the execution of constitutional freedoms and rights can be established only by the legislative authority and only in the 
form of an act. Second, restrictions can be established if they are necessary in a democratic state. Third, restrictions should pursue legitimate aims such as public safety or order, environmental protection, protection of public health and morality, protection of the freedoms and rights of others. This provision sets the limits for the interference of public authority in the sphere of constitutional rights and freedoms of the individual.

Since the content of Article 31 paragraph 3 of the Constitution concerns the limitation of freedoms and rights, it must be treated as an exemption, because it narrows the scope of application of freedoms and constitutionally guaranteed rights. This provision applies to all constitutional freedoms and rights, regardless of whether specific provisions separately specify the conditions for limiting a given right and freedom. The sense of requiring a statutory form of restrictions on freedoms and rights is obvious. It ensures the participation of parliament in shaping the legal situation of the individual, and proclaims the openness of the decision-making process, protects against hasty and ill-considered measures, as well as allows to maintain government legislative activity. Article 31 paragraph 3 of the Constitution permits the establishment of restrictions on the execution of freedoms and rights only under the condition that it is necessary to achieve one of the six aims listed therein. Undoubtedly, it is primarily public authorities that are responsible for ensuring public security, public order, environmental protection, protection of public health and morality, protection of the freedoms and rights of others. Therefore, bearing the responsibility for achieving these aims, take advantage of the limits on the rights and freedoms of individuals due to these aims.

\section{IV.ECONOMIC, SOCIAL AND CULTURAL RIGHTS AND FREEDOMS IN THE CONSTITUTION}

Economic, social and cultural rights and freedoms are contained in Chapter II of the Constitution entitled "The freedoms, rights and obligations of persons and citizens". The discussed economic and cultural rights and freedoms embrace the following: 1) the right to ownership, other property rights and the right of 
succession (Article 64);2) the freedom to choose and to pursue occupation, as well as to choose the place of work (Article 65);3) the right to safe and hygienic conditions at work; the right to statutorily specified days free from work (Article 66); 4) the right to social security (Article 67); 5) the right to health protection (Article 68); 6) aid to disabled persons (Article 69); 7) the right to education (Article 70); 8) the right of the family to special assistance from public authorities (Article 71); 9) protection of the rights of the child (Article 72); 10) the freedom of artistic creation, scientific research, the freedom to teach and to enjoy the products of culture (Article 73); 11) ecological security and environmental protection (Article 74); 12) satisfying housing needs (Article 75); 13) consumer protection (Article 76).

\subsection{The Right to Property, Other Property Rights and the Right of Succession}

Pursuant to Article 64 of the Constitution:

1. Everyone shall have the right to property, other property rights and the right of succession. 2. Everyone, on an equal basis, shall receive legal protection regarding property, other property rights and the right of succession. 3. The right to property may only be limited by means of a statute and only to the extent that it does not violate the substance of such right.

In the judgment of 29 July 2013, the Constitutional Tribunal stated:

(...) pursuant to Article 64 (1) of the Constitution everyone has the right to property, other property rights and the right of succession. The said provision expresses an individual right encompassing the freedom to acquire, dispose of and retain property (...). It introduces the guarantee not only of acquiring property, but also of disposing of it (...). The right to dispose of a thing (ius dispositivum) signifies the possibility to freely retain ownership of a specified thing by its owner as long as this reflects his/her wish, and to freely transfer property right to another person of the individual's choice under individually accepted conditions (...). ${ }^{1}$

The aforementioned provision is to be understood as a general systemic rule, recognition of private ownership, not only as one of the fundamental

The Decision No. SK 12/12 (the Constitutional Tribunal of Poland, 29 July 2013): 11. 
institutions of the Polish economic order, but also as one of the fundamental values, on the basis of which the Polish social and legal order is established. ${ }^{2}$

Article 64 of the Constitution indicates aside ownership, also "other property rights" and "the right of succession". Other property rights embrace rights, which have a financial asset, and which may constitute an element of individuals' property and realize a specific property interest. In the light of the case law of the Constitutional Tribunal, "other property rights" encompass inter alia allowance in lieu of paid annual leave not taken or entitlement to a claim based on unjust enrichment. The right of succession is a property right; nonetheless, in the light of Article 64 (1) and (2) of the Constitution, it constitutes an independent institution, i.e. it does not fall within the scope of ownership, nor within the scope of other property rights. The constitutional guarantee of the said right has above all a negative meaning and, in particular, it prohibits the legislator from abolishing that institution or from substantially restricting the circle of statutory heirs, as well as from depriving anyone of the capacity to succeed, as well as it prohibits the state from arbitrarily taking over (other subjects of public law) the property of the deceased. In other words, the legislator has no possibility to deprive elements of property of the deceased of the status of private property. ${ }^{3}$

\subsection{The Right to Safe and Hygienic Conditions of Work; The Right to Paid Holidays}

In accordance with Article 66 of the Constitution:

1. Everyone shall have the right to safe and hygienic conditions of work. The methods of implementing this right and the obligations of employers shall be specified by statute. 2 . An employee shall have the right to statutorily specified days free from work as well as annual paid holidays; the maximum permissible hours of work shall be specified by statute.

Lech Garlicki and Marek Zubik, Konstytucja Rzeczypospolitej Polskiej. Komentarz [Constitution of the Republic of Poland. A Commentary] (Warszawa: Wydawnictwo Sejmowe, 2016), 589.

Garlicki and Zubik, Konstytucja Rzeczypospolitej Polskiej [Constitution of the Republic of Poland], 589. 
The right to safe and hygienic conditions of work is a typical social right, aimed to protect safe and hygienic conditions of work, whereas its scope ratione personae embraces everyone who performs work. This means that the subject of review may encompass all provisions determining the conditions of work in the light of the constitutional standards. The aforementioned provision also places an obligation on the employer to introduce regulations that conform to the constitutional standards.

The right to statutorily specified days free from work as well as annual paid holidays is a constitutional guarantee of the right to rest. The said right is specified in the Labour Code.

\subsection{The Right to Social Security}

Pursuant to Article 67 of the Constitution:

1. A citizen shall have the right to social security whenever incapacitated for work by reason of sickness or invalidism as well as having attained retirement age. The scope and forms of social security shall be specified by statute. 2. A citizen who is involuntarily without work and has no other means of support, shall have the right to social security, the scope of which shall be specified by statute.

This provision concerns the right to social security, i.e. every citizen who is not able to perform work as a result of a disease or invalidity, is entitled to receive cash and non-cash benefits, specified by statute. Above all, cash benefits paid on account of incapacity for work, as well as broadly understood social assistance (e.g. courses, trainings, essential clothing, meals) are concerned.

Moreover, the said provision stipulates that unemployed citizens have the right to social security, that is, to cash and non-cash benefits received by persons who have been involuntarily unemployed. The scope and form of the said aid is specified by statute.

The aforementioned provision is directed at public authorities, which are obliged to establish social security system and to maintain the said 
system, so as to implement the constitutional guarantees of social security on a continuous basis.

\subsection{The Protection of Health}

In accordance with Article 68 of the Constitution:

Everyone shall have the right to have his health protected. 2. Equal access to health care services, financed from public funds, shall be ensured by public authorities to citizens, irrespective of their material situation. The conditions for, and scope of, the provision of services shall be established by statute. 3. Public authorities shall ensure special health care to children, pregnant women, handicapped people and persons of advanced age. 4. Public authorities shall combat epidemic illnesses and prevent the negative health consequences of degradation of the environment. 5. Public authorities shall support the development of physical culture, particularly amongst children and young persons.

The indicated provision gives everyone the right to use the health care system, the aim of which is to eliminate and prevent conditions other than the highest attainable standard of health of the human body. The said right is exercised by means of non-cash benefits (in particular treatment and rehabilitation). The provision contained in Article 68 (2) of the Constitution refers to "equal access to health care services". This right corresponds with the obligation of public authorities to establish public health care system and to ensure the effectiveness thereof. The state is obliged to ensure funds in the state budget to finance public health care system. Special health care is ensured to children, pregnant women, handicapped people and persons of advanced age. Besides, public authorities are obliged to support the development of physical culture, which is to be understood as preventive health care.

\subsection{Aid Provided to Disabled Persons}

Pursuant to Article 69 of the Constitution: "Public authorities shall provide, in accordance with statute, aid to disabled persons to ensure their subsistence, adaptation to work and social communication". 
The Constitution imposes an obligation on public authorities to provide aid to ensure subsistence, adaptation to work and social communication. The definition of "disability" should be contained in a statute which should refer to international regulations in that regard. However, there is no doubt as to the fact that disability refers both to limitations of physical and mental functions. In practice, aid provided to disabled persons embraces both material (e.g. cash benefits) and immaterial assistance (e.g. professional courses, charge-free access to public transport). The obligation to provide aid to disabled persons may also be fulfilled by means of the institutions of legal incapacitation and finally of a guardian.

\subsection{The Right to Education}

In accordance with Article 70 of the Constitution:

1. Everyone shall have the right to education. Education to 18 years of age shall be compulsory. The manner of fulfilment of schooling obligations shall be specified by statute. 2. Education in public schools shall be without payment. Statutes may allow for payments for certain services provided by public institutions of higher education. 3. Parents shall have the right to choose schools other than public for their children. Citizens and institutions shall have the right to establish primary and secondary schools and institutions of higher education and educational development institutions. The conditions for establishing and operating non-public schools, the participation of public authorities in their financing, as well as the principles of educational supervision of such schools and educational development institutions, shall be specified by statute. 4. Public authorities shall ensure universal and equal access to education for citizens. To this end, they shall establish and support systems for individual financial and organizational assistance to pupils and students. The conditions for providing of such assistance shall be specified by statute. 5. The autonomy of the institutions of higher education shall be ensured in accordance with principles specified by statute.

The above-mentioned provision refers to the possibility and obligation (to 18 years of age) to acquire knowledge (education), in an organised, regular and continuous manner. Education leads to obtaining certificates, which entitle to continue education or to perform a certain profession in 
the country, and in many cases also abroad. The said provision relates to public schools - administered by public authorities and in principle free of charge, and to non-public schools (private). Pedagogical supervision of the latter is provided by public authorities. The educational cation system is regulated by a statute. Public authorities are obliged to ensure equal access to education for everyone, including also by means of material assistance (financial aid granted on the basis of income).

\subsection{The Right of the Family to Assistance from Public Authorities}

In accordance with Article 71 of the Constitution:

The State, in its social and economic policy, shall take into account the good of the family. Families, finding themselves in difficult material and social circumstances - particularly those with many children or a single parent - shall have the right to special assistance from public authorities. 2. A mother, before and after birth, shall have the right to special assistance from public authorities, to the extent specified by statute.

The aforementioned provision concerns two issues. Firstly, the obligations of public authorities in relation to the "family". Secondly, assistance, related to childbirth, provided to a mother.

The following are recognised as a relevant feature of a family community from the legal point of view: close and lasting relationships between family members of emotional, economic and financial character. Public authorities have an obligation to "take into account the good of the family" in their social and economic policy. What could serve as an example of the violation of the aforementioned provision is a situation where the legislator misinterprets the constitutional provision indicating a specified objective or task of public authorities, in particular, if the legislator, while enacting a statute, applied such measures which could not lead to the attainment of that objective. ${ }^{4}$ Families, finding themselves in difficult material and social circumstances - particularly those with many children or a single parent -

The Decision of the Constitutional Tribunal of Poland Number K 11/oo, dated 4 April 2001 : 31. 
may receive special assistance from public authorities. Such assistance must therefore exceed the scope of the regular form of "taking into account of the good of the family".

Article 71 (2) of the Constitution concerns the situation of a mother, and thus it is linked with the principle of maternity protection. Benefits, which may be accorded to mothers, are specified by statute and mothers may apply for the said benefits within the scope specified by statute. It is noteworthy that the said provision refers to every mother, not only to the mothers finding themselves in difficult material and social circumstances. The aforementioned provision embraces also mothers - foreigners.

\subsection{Protection of The Rights of the Child}

In accordance with Article 72 of the Constitution:

1. The Republic of Poland shall ensure protection of the rights of the child. Everyone shall have the right to demand of organs of public authority that they defend children against violence, cruelty, exploitation and actions which undermine their moral sense. 2. A child deprived of parental care shall have the right to care and assistance provided by public authorities. 3. Organs of public authority and persons responsible for children, in the course of establishing the rights of a child, shall consider and, as much as possible, give priority to the views of the child. 4. The competence and procedure for appointment of the Ombudsman for Children's Rights shall be specified by statute.

The said provision regulates a number of issues: 1) it imposes an obligation on public authorities to ensure protection of the rights of the child, which is related to "everyone's" right to demand protection of a child against particularly drastic infringement of those rights; 2) it establishes the principle of the superior role of parents in guardianship and the subsidiary role of public authorities in that regard; 3) it recognises the child as the subject of rights and obligations, and the procedural rights of a child arising therefrom; 4) it provides for the requirement to establish the office of the Ombudsman for Children's Rights. 
The content of the obligation of public authorities - to ensure protection of the rights of the child - is not specified. The legislator is vested with the responsibility for the indication of specific tasks and forms of activity of public authorities. Everyone has the right to demand from organs of public authority to protect the child against the above-mentioned problems. This is a special kind of actio popularis, because in order to make such a demand, it is not necessary to indicate a specific legal interest or a specific relation to a given child. The responsible public authority should examine and reply to a "demand". The legislator is obliged to specify the said procedure. Public authorities have a special obligation to provide assistance to a child deprived of parental care. Article 72 (3) of the Constitution imposes on every organ of public authority and on every person responsible for a child, the obligation to consider and, insofar as possible, give priority to the views of the child in the course of establishing the rights of a child. The said obligation is directed both at organs of public authority as well as parents of a child. Article 72 (4) envisages the establishment of the office of the Ombudsman for Children's Rights. Granting the Ombudsman, the status of a constitutional organ is an exceptional solution from the perspective of other legal systems, in which the sole basis for the functioning of the Ombudsman for children's rights is constituted by statutes.

\subsection{The Freedom of Artistic Creation, Scientific Research, the Freedom to Teach and to Enjoy the Products of Culture}

In accordance with Article 73 of the Constitution: "The freedom of artistic creation and scientific research as well as dissemination of the fruits thereof, the freedom to teach and to enjoy the products of culture, shall be ensured to everyone". The said provision concerns a number of issues: 1) the freedom of artistic creation; 2) the freedom of scientific research and the freedom to teach; 3 ) the freedom to enjoy the products of culture.

The freedom of artistic creation embraces the freedom to create works of art without interference by public authority with the process of the creation of such work. The freedom of artistic creation also encompasses the 
freedom to publicly exhibit works of art. It is arguable whether the products of every artistic creation enjoy the freedom to be publicly exhibited to an indefinite number of recipients. In particular, this concerns "works of art" which may violate e.g. the rights and freedoms of others.

The freedom to teach embraces the liberty to conduct scientific research and to educate. What is concerned is the freedom to make findings on the basis of the criterion of truth, which then may be verified and assessed. Everyone may freely choose the subject of research, the research method and the manner of presenting research results. The content of the freedom to teach is to ensure the liberty to systematically impart scientific knowledge to other persons. The freedom to teach is realised in particular at the university level. However, public authorities may shape the curriculum and may establish eligibility requirements for teachers.

The freedom to enjoy the fruits of culture refers to providing access to the products of artistic creation of others. Everything, which has been legally created and made available to the public, should be available to "everyone". The restriction of the freedom to enjoy the fruits of culture may arise from e.g. the necessity to protect the morale of persons under 18 (children).

\subsection{Ecological Security and Protection of the Environment}

In accordance with Article 74 of the Constitution:

1. Public authorities shall pursue policies ensuring the ecological security of current and future generations. 2. Protection of the environment shall be the duty of public authorities. 3. Everyone shall have the right to be informed of the quality of the environment and its protection. 4. Public authorities shall support the activities of citizens to protect and improve the quality of the environment.

Public authorities have a number of obligations related to environmental protection: 1) pursuing policies ensuring the ecological security of current and future generations; 2) providing information concerning the quality of the environment and its protection; 3) supporting the activities of citizens 
to protect and improve the quality of the environment. The realisation of the said obligations takes place both at the level of legislation by means of enacting appropriate provisions, as well as at the level of the application of law by means of issuing individual decisions.

The scope ratione personae of the right to be informed, as referred to in Article 74 (3), encompasses everyone, i.e. both a citizen of the Republic of Poland, as well as a foreigner. The obligation to provide information is directed at public authorities.

\subsection{Satisfying the Housing Needs}

In accordance with Article 75 of the Constitution:

1. Public authorities shall pursue policies conducive to satisfying the housing needs of citizens, in particular combating homelessness, promoting the development of low-income housing and supporting activities aimed at acquisition of a home by each citizen. 2. Protection of the rights of tenants shall be established by statute.

The said provision imposes an obligation on public authorities to satisfy the housing needs of citizens, in particular to combat homelessness, promote the development of low-income housing and support activities aimed at acquisition of a home by each citizen. The aforementioned obligation should be realised both by means of enacting appropriate provisions, as well by means of issuing individual decisions implementing the aforementioned provisions contained in Article 75 of the Constitution. As regards the enactment of the law, the authorities have an obligation, in particular, to enact law on the protection of the rights of tenants.

\subsection{Consumer Protection}

In accordance with Article 76 of the Constitution: "Public authorities shall protect consumers, customers, hirers or lessees against activities threatening their health, privacy and safety, as well as against dishonest market practices. The scope of such protection shall be specified by statute".

The said provision indicated the obligation of public authorities to protect the following goods: health, privacy, safety, as well as to protect 
against dishonest market practices in relations in which consumers (persons who enter legal actions with traders), users and hirers are one of the parties. The said obligation is implemented, in particular, by means of enacting appropriate statutes aimed at the protection of the aforementioned goods. Aside from the legislature, also the authorities, adjudicating on the individual situation of consumers, may be recognised as the addressees of the said provision.

\section{RELATIONS BETWEEN THE POLISH LEGAL SYSTEM AND THE SYSTEM OF THE CONVENTION FOR THE PROTECTION OF HUMAN RIGHTS AND FUNDAMENTAL FREEDOMS}

In a situation of convergence of national and international competences, i.e. when both national and international entities can perform the same specific activity, there is a need to refer to the principle of subsidiarity. ${ }^{.}$The general question of whether these competencies can be exercised differently (but not arbitrarily) at national and international level should be answered in the affirmative, and this is due to the very essence of the principle of subsidiarity, which - in the opposite case - would be superfluous. The subsidiarity principle does not apply to exclusive competences reserved only for one entity.

The principle of subsidiarity, understood as above, applies to the relations between the ECHR and the courts of the States - parties to the Convention for the Protection of Human Rights and Fundamental Freedoms (hereinafter: the Convention) - which rule on human rights and freedoms. In international human rights law, there is an inherent tension between the affirmation of the universal, material vision of human dignity and respect for the diversity and freedom of human cultures. ${ }^{6}$

P.G. Carozza stated that subsidiarity requires:

First, that local communities be left to protect and respect the human dignity and freedom represented by the idea of human rights whenever

Sabino Cassese, "Ruling Indirectly. Judicial Subsidiarity in the ECtHR" (A seminar paper at European Court of Human Rights, 2015),10, https://www.echr.coe.int/Documents/Speech_20150130_Seminar_Cassese_ENG.pdf.

6 Paolo Carozza, "Subsidiarity as a Structural Principle of International Human Rights Law," American Journal of International Law 97 (2003) : 38. 
they are able to achieve those ends on their own; (...). Second, subsidiarity supports the integration of local and supranational interpretation and implementation into a single community of discourse with respect to the common good that the idea of human rights represents. And third, to the extent that local bodies cannot accomplish the ends of human rights without assistance, the larger communities of international society have a responsibility to intervene. Insofar as possible, however, the subsidium of the larger community should be oriented toward helping the smaller one achieve its goal without supplanting or usurping the latter society's freedom to pursue its own legitimate purposes. ${ }^{7}$

In the Convention, a kind of respect for the state authorities - parties to this act, was expressed by requiring the exhaustion of the domestic remedies before lodging an application with the ECHR. This is to ensure mutual and correct interaction between national and conventional legal orders. ${ }^{8}$ The principle of subsidiarity understood in this way was formally expressed in Article 35 of the Convention, which provides as follows: "1. The Court may only deal with the matter after all domestic remedies have been exhausted, according to the generally recognized rules of international law, and within a period of six months from the date on which the final decision was taken. (...)." At the same time, in accordance with Article 13 of the Convention, States - parties to the Convention are obliged to provide everyone, whose rights and freedoms as set forth in the Convention are violated, an effective remedy before a national authority notwithstanding that the violation has been committed by persons acting in an official capacity. The subsidiarity principle was strengthened by Protocol 15 to the Convention, on the basis of which the following sentence has been added to the Introduction to the Convention:

Affirming that the High Contracting Parties, in accordance with the principle of subsidiarity, have the primary responsibility to secure the rights and freedoms defined in this Convention and the Protocols thereto, and that in doing so they enjoy a margin of appreciation, subject to the supervisory jurisdiction of the European Court of Human Rights established by this Convention.

Carozza, "Subsidiarity as a", 57.

8 Cassese, "Ruling Indirectly," 4. 
It is said that the above paragraph is, inter alia, a response to a significant number of cases before the ECHR. ${ }^{9}$

In my opinion, the principle of subsidiarity, understood as exhaustion of the domestic remedies before lodging an application with the ECHR, is a principle of subsidiarity in terms of procedure. On the substantive side, however, the doctrine of the margin of appreciation sets out the subsidiarity principle. The principle of subsidiarity has therefore in my opinion two dimensions: procedural and substantive.

It seems clear that national authorities, in particular the courts, are in a better position to determine facts of a particular case, to take evidence in the case, or to determine which provisions of law to apply. There are, however, situations in which the ECHR is ready to grant a broad (broader) scope of freedom to national authorities, referring to the doctrine of the margin of appreciation formed in the case law of the ECHR. At the same time, in my opinion, it is a substantive aspect of the subsidiarity principle. The margin of appreciation doctrine was created by the ECHR in its case law. It refers to "(...) the breadth of deference or error the Court will allow national bodies before it will declare a violation of one of the substantive guarantees under the Convention". ${ }^{\circ}$ For the record, it should be noted that for the first time the ECHR referred to the doctrine of the margin of appreciation in its judgment of 7 December of 1976 in the case of Handyside $v$. The United Kingdom, in which we read:

The Court points out that the machinery of protection established by the Convention is subsidiary to the national systems safeguarding human rights (...). The Convention leaves to each Contracting State, in the first place, the task of securing the rights and liberties it enshrines. The institutions created by it make their own contribution to this task but they become involved only through contentious proceedings and once all domestic remedies have been exhausted. These observations apply, notably, to Article 10 para. 2 (art. 10-2). In particular, it is not possible to find in the domestic law of the various Contracting States a uniform European conception of morals. The view taken by their respective laws of the requirements of morals

\footnotetext{
9 Marisa Iglesias Vila, "Subsidiarity, Margin of Appreciation and International Adjudication within a Cooperative Conception of Human Rights," International Journal of Constitutional Law 15 (April 2017): 394.

10 Carozza, "Subsidiarity as $a_{1}$ " 61.
} 
varies from time to time and from place to place, especially in our era which is characterised by a rapid and far-reaching evolution of opinions on the subject. By reason of their direct and continuous contact with the vital forces of their countries, State authorities are in principle in a better position than the international judge to give an opinion on the exact content of these requirements (...)."

The doctrine of the margin of appreciation causes a lively discussion among representatives of science. ${ }^{2}$ The advocates of this doctrine indicated, among other things, e.g.: 1) that the scope of violations of the Convention rights and freedoms where the doctrine of the margin of appreciation can be applied, is limited, ${ }^{13} 2$ ) that the doctrine of the margin of appreciation may be appropriate, in particular in cases where there is a reasonable doubt as to whether the State - party to the Convention violated the rights or freedoms of the Convention, due to a somewhat better understanding of the circumstances of the case by national courts; ${ }^{14} 3$ ) the ECHR even in such a case as the one in point 2 , using the so-called proportionality test, may confirm the decisions of national authorities. ${ }^{15}$ The opponents of the doctrine of the margin of appreciation point out, among other things, that e.g. the idea that States Parties to the Convention have a margin of appreciation in fulfilling their human rights obligations, and that these human rights obligations should correspond to the level of diversity

11 Decision of the European Court of Human Rights Number 5493/72, Handyside v. the United Kingdom (European Court of Human Rights, 7 December 1976), 17.

12 See Andreas Follesdal and Nino Tsereteli, "The Margin of Appreciation in Europe and Beyond," The International Journal of Human Rights (2016): 1055 - 1057, https://doi.org/10.1080/13642987.2016.1258856; Dimitrios Tsarapatsanis, "The Margin of Appreciation as an Underenforcement Doctrine," in Human Rights Between Law and Politics. The Margin of Appreciation in Post-National Contexts. Modern Studies in European Law, ed. Petr Agha (Hart Publishing, 2017); Andreas Follesdal, "Appreciating the Margin of Appreciation," in Human Rights: Moral or Political, ed. A. Etinson (Oxford: Oxford University Press, 2018); Georg Letsas, "The Margin of Appreciation Revisited A Response to Follesdal", in Human Rights: Moral or Political, ed. A. Etinson, (Oxford: Oxford University Press, 2018); Andreas von Staden, "The Democratic Legitimacy of Judicial Review beyond the State: Normative Subsidiarity and Judicial Standards of Review," International Journal of Constitutional Law 10, no. 4 (October 2012): 1028, https://doi.org/10.2139/ssrn.1969442; Oddný Mjöll Arnardóttir, "Rethinking the Two Margins of Appreciation," European Constitutional Law Review (December 2016): 28; Stefan Graziadei, "Democracy v. Human Rights? The Strasbourg Court and the Challenge of Power Sharing," European Constitutional Law Review (December 2016): 54-84, https://doi.org/10.1017/S1574019616000043; Amrei Müller, "Domestic authorities' Obligations to Co-Develop the Rights of the European Convention on Human Rights", The International Journal of Human Rights (October 2016): 1058-1076, https://doi.org/10.1080/13642987.2016.1242301.

13 Andreas Follesdal, "Appreciating the Margin of Appreciation," in Human Rights: Moral or Political, ed. A. Etinson (Oxford: Oxford University Press, 2018), 269.

14 Follesdal, "Appreciating the Margin," 269.

15 Follesdal, "Appreciating the Margin," 269. 
between States Parties to the Convention, is trivial or misleading. ${ }^{16}$ There are also opinions saying that it is necessary to distinguish between the issue of establishing (the literal wording of the so-called limitation clauses) and the issue of applying the law.17

\section{THE RIGHT TO PROPERTY - THE CONFRONTATION OF THE POLISH LEGAL SYSTEM WITH THE SYSTEM OF THE CONVENTION: A CASE STUDY}

\subsection{The Case of Waldemar Nowakowski v. Poland (application no. 55167/11)}

The case originated in an application against the Republic of Poland lodged with the Court under Article 34 of the Convention by a Polish national, Mr. Waldemar Nowakowski (hereinafter: the applicant), on 22 August 2011. ${ }^{18}$ The applicant complained about an alleged breach of his right to the peaceful enjoyment of his possessions guaranteed by Article 1 of Protocol No. 1 to the Convention. ${ }^{19}$

The circumstances of the case were as follows.

The applicant was a veteran of the Polish Resistance during the Second World War and a former professional officer of the Polish Army. His veteran status on the grounds of his involvement in the underground Scouts movement during that war was recognized by an administrative decision given on an unspecified date by the Director of the Veterans' Office. For the last fifty years, the applicant collected antique arms and weapons from the period of the Second World War and earlier.

\footnotetext{
Letsas, "The Margin of," 295.

17 D. Tsarapatsanis, "The Margin of," 71-88.

18 Decision of European Court and Human Rights No. 55167/11, Waldemar Nowakowski v. Poland (European Cour and Human Rights 24 July 2012): 2.

19 Article 1 of Protocol no. 1 to the Convention: "Every natural or legal person in entitled to the peaceful enjoyment of his possessions. No one shall be deprived of his possessions except in the public interest and subject to the conditions provided for by law and by the general principles of international law. 2 . The preceding provisions shall not, however, in any way impair the right of a State to enforce such laws as it deems necessary to control the use of property in accordance with the general interest or to secure the payment of taxes or other contributions or penalties".
} 
On 7 and 8 July 2008, the police searched the applicant's home and summer cottage. They confiscated the applicant's collection, which at that time numbered 199 pieces.

On 16 July 2008 the Director of the Warsaw Uprising Museum (hereinafter: the Museum) in Warsaw issued a statement for the purposes of an investigation against the applicant which had been instituted immediately after the search and seizure. He stated that, the applicant had been cooperating with the Museum as a specialist in old weaponry and that on a number of occasions he had lent certain pieces of his collection for the purposes of their being exhibited at the Museum. He stated that the applicant's expertise was highly valued by the Museum.

On 18 November 2010, the Warszawa Wola District Court discontinued the criminal proceedings against the applicant concerning charges of illegal possession of arms, contrary to Article 263 Section 2 of the Criminal Code. The court first listed 171 pieces of the applicant's collection, the oldest of them produced in 1889. The court acknowledged that no criminal intent to use the arms to anyone's detriment could reasonably be ascribed to the applicant. However, he must have known that the possession of arms without a permit was unlawful. The court concluded that the offence was minor in nature and discontinued the criminal proceedings against the applicant, referring to Article 17 paragraph 1 (3) of the Criminal Code. At the same time, the court decided to apply Article 100 of the Criminal Code in conjunction with its Article 39 and to confiscate 171 pieces of the collection. The court, explaining why it decided to avail itself of its discretionary power to confiscate the entire collection, stated that dividing up the collection by returning to the applicant those pieces which had already been put out of action would seriously diminish its value. It noted that the collection should, because of its historical interest, be handed over to an institution capable of securing appropriate storage and display conditions for it.

By a decision of 22 February 2011, the Warsaw Regional Court upheld the first-instance decision. It fully endorsed the reasoning of the lower 
court. It further noted that the confiscation of the collection should not lead to its destruction. The State authorities should be well aware of the historical value of the collection. On 16 March 2011, the Warszawa Wola District Court invited the Warsaw Uprising Museum to indicate whether they would be interested in the applicant's collection. On 28 June 2011, the Director of the Museum replied, indicating that the Museum wished to take certain pieces selected by a Museum's expert.

The applicant complained to the Court that the confiscation of his collection had breached his right to the peaceful enjoyment of his possessions within the meaning of Article 1 of Protocol No. 1 to the Convention. Article 1 of Protocol No. 1 to the Convention comprises three distinct rules. The first, which is expressed in the first sentence of the first paragraph and is of a general nature, lays down the principle of peaceful enjoyment of property. The second rule, in the second sentence of the same paragraph, covers deprivation of possessions and makes it subject to certain conditions. The third, contained in the second paragraph, recognizes that the Contracting States are entitled, among other things, to control the use of property in accordance with the general interest. The second and third rules, which are concerned with particular instances of interference with the right to peaceful enjoyment of property, must be construed in the light of the general principle laid down in the first rule.

The Court held that it was not in dispute between the parties that the confiscation order had amounted to an interference with the applicant's right to peaceful enjoyment of his possessions. It remained to be determined whether the measure was covered by the first or second paragraph of that Convention provision.

The Court noted that the confiscation of the applicant's property was ordered pursuant to Article 100 of the Criminal Code in conjunction with its Article 39. It therefore accepted that interference was prescribed by law. Furthermore, assuming that the interference complained of pursued 
a legitimate aim in the general interest, within the meaning of Article 1 of Protocol No. 1 to the Convention, the Court had to examine whether a proper balance had been struck between that aim and the applicant's rights. In this connection, the Court reiterated that, where possessions are confiscated, the fair balance depends on many factors, including the owner's behavior. It must have therefore determined whether the Polish courts had regard to the applicant's degree of fault or care

The Court noted that Article 100 of the Criminal Code did not oblige the courts to order the forfeiture of the collection. It only conferred on them a discretionary power to do so when discontinuing criminal proceedings. The courts decided to avail themselves of that power.

The ECHR stated that the first-instance court noted that the applicant was a 77 year old war veteran, had fought in the Warsaw Uprising, was a retired professional officer of the Polish Army and was a law-abiding citizen with no criminal record. The Court further stressed that the domestic courts were aware of these circumstances. However, they still decided to confiscate the collection. The applicant's personal circumstances did not therefore have any practical impact on the confiscation order. The Court was therefore of the view that the domestic courts failed to take into account the applicant's personal situation and characteristics.

The Court could not but note that the applicant started his collection approximately fifty years ago. The domestic court acknowledged this fact in its decision. The authorities had never taken any interest in the collection before July 2008 when they searched the applicant's home and summer cottage. The Court further observed that the domestic court was aware that not all the pieces of the collection could still be used as weapons as the applicant had taken measures to disable them. The domestic courts failed to consider any alternative measures which could have been taken in order to alleviate the burden imposed on the applicant, including by way of seeking registration of the collection. 
Having regard to the above, the ECHR found that the applicant had been deprived of his property, losing the collection of considerable historical and financial value. Therefore, Poland violated Article 1 of Protocol No. 1 to the Convention.

The Court was of the view that in the circumstances of the case the most appropriate form of redress of the violation found would be the restitution to the applicant of those elements of the collection which could be lawfully restored to him. Moreover, the Court accepted that the applicant undoubtedly suffered distress and anxiety. It therefore awarded him EUR 4,ooo in respect of nonpecuniary damage.

\subsection{The Execution of the Case of Waldemar Nowakowski v. Poland by the Polish Government}

The obligation to execute (implement) the ECHR's judgments by the Member States of the Council of Europe results from Article 46 of the Convention. The Committee of Ministers of the Council of Europe, which is the sole decision-making body of the Council of Europe, supervises the execution of judgments of the ECHR. It consisted of the Member States' foreign ministers.

In order to ensure the best implementation of judgments of the ECHR, on 19 July 2007, the Prime Minister of Poland appointed the Inter-Ministerial Team for the ECHR (hereinafter: the Team). The team acts as an advisory body to the Prime Minister. The tasks of the Team include developing government opinions on communicated cases and judgments of the ECHR, analyzing compliance with the Convention of major draft legal acts, as well as presenting appropriate proposals. At the meetings of the Team, problems arising from communicated complaints and judgments issued by the ECHR are analyzed. The Team may make proposals for appropriate actions. It is also a forum where particularly significant problems are discussed regarding the compliance of the proposed statutory changes with the Convention, which may be related to laws or practices in Poland. 
The Team supervises the execution of judgments and decisions of the ECHR against Poland based on documents and information on the execution of judgments and decisions submitted by relevant ministers on their own initiative or at the request of the minister competent for foreign affairs, and analyses possible problems related to their implementation. The Team performs the task, in terms of supervising the implementation of the ECHR judgments and decisions, in particular on the basis of an action plan presented by the minister competent because of the content of the violation found in the ECHR judgment, containing information on required measures, i.e.: 1) individual measures, in other words measures to ensure that a violation of the Convention will be terminated and that the applicant will be placed, as far as possible, in the same position as he enjoyed before the violation of the Convention; 2) general measures, i.e. measures concerning law or practice aimed at ending the violation of the Convention and preventing new, similar violations of the Convention in the future. The action plan should also include a deadline for implementing individual or general measures.

As regards the judgment in the case of Waldemar Nowakowski v. Poland, the following individual measures were taken, of which the Polish government informed the Committee of Ministers in its report of 2 September 2015. On 26 November 2013, the Warsaw Court of Appeal re-opened the criminal proceedings against the applicant and remitted the case to the first-instance court. The Government had submitted to the domestic court their amicus curiae in the applicant's favour.

On 13 February 2014 the Warsaw District Court, having regard to the Court's principal judgment of 24 July 2012, annulled the decision to confiscate the collection. The court noted that the applicant had fulfilled applicable administrative formalities necessary for running a private museum. In particular, he had obtained a relevant permit of the Ministry of Culture and National Heritage. It further confirmed the applicant's ownership of the collection. The collection was returned to the applicant on 9 April 2014. 
Regarding general measures, the Polish government stated that the ECHR did not criticized a legal framework governing confiscation as contained in the Polish Criminal Code, but rather its application in the specific circumstances of this particular case. In the government's opinion, the publication of the above judgment will be sufficient measure to prevent future similar violations. In the government's view, no further individual measures are necessary in this case and the general measures adopted will be sufficient to conclude that Poland fulfilled its obligations under Article 46 paragraph 1 of the Convention.

In its resolution of 14 September 2015, the Committee of Ministers, exercising its powers pursuant to Article 46 paragraph 2 of the Convention, stated as follows:

Having examined the action report provided by the government indicating the measures adopted in order to give effect to the judgment including the information provided regarding the payment of the just satisfaction awarded by the Court. Having satisfied itself that all the measures required by Article 46, paragraph 1, have been adopted, declares that it has exercised its functions under Article 46, paragraph 2, of the Convention in this case and decides to close the examination thereof. ${ }^{20}$

\section{CONCLUSION}

In the Polish legal order, primarily in the Constitution, there exists a significant number of economic, social and cultural rights and freedoms. They are clarified in the course of proceeding in a specific case. The right to property is one of the fundamental rights. The practice of applying the law by Polish courts and the ECHR shows that a different approach to the interpretation of the right to property (and other rights as well) occurs. Nevertheless, the Polish government implement judgments and decisions of the ECHR by means of individual and general measures. At the same time, it should be stated that a

\footnotetext{
20 Resolution of the Committee of Ministers of the Council of Europe of 14 September 2015, https://hudoc.echr. coe.int/eng\#\{"itemid":["001-158387"]\}.
} 
different interpretation of the law at domestic and international level is not completely prohibited. In a way, its theoretical justification is the principle of subsidiarity and the doctrine of the margin of appreciation.

\section{BIBLIOGRAPHY}

Carozza, Paolo. "Subsidiarity as a Structural Principle of International Human Rights Law." American Journal of International Law (2003).

Committee of Ministers of the Council of Europe. "Resolution of 14 September 2015." 2015.

Follesdal, Andreas. "Appreciating the Margin of Appreciation." In Human RIghts: Moral or Political? edited by Adam Etinson , 269-294. Oxford: Oxford University Press, 2018.

Follesdal, Andreas and Nino Tsereteli. "The Margin of Appreciation in Europe and Beyond." The International Journal of Human Rights (December 2016).

Garlicki, Lech and Marek Zubik. Konstytucja Rzeczypospolitej Polskiej. Komentarz. [Constitution of the Republic of Poland. A Commentary]. Warszawa: Wydawnictwo Sejmowe, 2016.

Graziadei, Stefan. "Democracy v Human Rights? The Strasbourg Court and the Challenge of Power Sharing." European Constitutional Law Review (2016).

Vila, Marisa Iglesias. "Subsidiarity, Margin of Appreciation and International Adjudication within a Cooperative Conception of Human Rights." International Journal of Constitutional Law 15 (June 2017).

Letsas, Georg. "The Margin of Appreciation Revisited A Response to Follesdal." In Human Rights: Moral or Political, edited by Adam Etinson. Oxford: Oxford University Press, 2018.

Mjöll Arnardóttir, Oddný. "Rethinking the Two Magins of Appreciation." European Constitutional Law Review (2016). 
Müller, Amrei. "Domestic Authorities' Obligations to Co-Develop the Rights of the European Convention on Human Rights." The International Journal of Human Rights (October 2016).

Cassese, Sabino. "Ruling Indirectly. Judicial Subsidiarity in the ECtHR." A seminar paper at European Court of Human Rights, 2015),10, https://www.echr.coe. int/Documents/Speech_20150130_Seminar_Cassese_ENG.pdf

The Decision No. SK 12/12 (the Constitutional Tribunal of Poland, 29 July 2013): 11.

Tsarapatsanis, Dimitrios. "The Margin of Appreciation as an Underenforcement Doctrine." In Human Rights Between Law and Politics. The Margin of Appreciation in Post-National Contexts. Modern Studies in European Law, edited by Petr Agha, 71-88.

Von Staden, Andreas. "The Democratic Legitimacy of Judicial review beyond the state: Normative subsidiarity and judicial standards of review." International Journal of Constitutional Law (2012). 